Металлофиз. новейшие технол. / Metallofiz. Noveishie Tekhnol. () 2014 ИМФ (Институт металлофизики 2014 , т. 36, № 6, сс. 841-856

Оттиски доступны непосредственно от издателя

им. Г. В. Курдюмова НАН Украины)

Фотокопирование разрешено только

Напечатано в Украине.

в соответствии с лицензией

PACS numbers: 61.72.Hh, 61.72.J-, 62.40.+i, 66.30.-h, 81.30.Hd, 81.40.Np

\title{
Hydrogen-Induced Effects in Annealed and Prestrained 316L-Type Stainless Steel Studied by Means of Mechanical Spectroscopy
}

\author{
V. M. Shyvaniuk \\ G.V.Kurdyumov Institute for Metal Physics, N.A. S. of Ukraine, \\ 36 Academician Vernadsky Blvd., \\ UA-03680 Kyyiv-142, Ukraine
}

Annealed and tensile prestrained 316L-type stainless steel is studied by internal friction (IF) method. Low-frequency forced-vibration measurements of IF are carried out in the temperature range of $130-500 \mathrm{~K}$ before and after gaseous-hydrogen charging at $543 \mathrm{~K}$ and under three different pressures: $0.5,10$, and $100 \mathrm{MPa}$. Two complex multicomponent IF peaks at about 250 and $365 \mathrm{~K}$ are detected after preliminary tensile deformation in hydrogenfree material. As revealed, the low-temperature peak is of relaxation type, and the high-temperature one is a resonant peak. The effect of hydrogen content and hydrogen distribution on IF peaks' features, e.g., background, amplitude and thermal stability, is examined. An increase in stability of vacancies caused by hydrogen is suggested that follows from IF measurements after ageing at $473 \mathrm{~K}$. As experimentally shown, the temperature drop of hydrogenation to $358 \mathrm{~K}$ leads to a marked shift of the high-temperature peak toward higher temperatures. A hypothesis about the cause underlying this phenomenon is proposed.

За допомогою механічної спектроскопії, а саме, міряння внутрішнього тертя, досліджено неіржавійну сталь типу $316 \mathrm{~L}$ у відпаленому та деформованому розтягом станах. Низькочастотні міряння внутрішнього тертя на вимушених коливаннях проводилися в температурному діапазоні від 130 до 500 К перед і після газового наводнювання при 543 К та трьох значеннях тиску водню: 0,5, 10 та 100 МПа. Після деформації розтягом у вихідному матеріалі виявлено два мультикомпонентних піки при температурах біля 250 та 365 К. Показано, що низькотемпературний пік має релаксаційну природу, в той час як високотемпературний пік відноситься до резонансних. Також було перевірено вплив вмісту водню та його розподілу на властивості піків внутрішнього тертя, а саме, на їх фон, амплітуду та термічну стабільність. Сформульовано припущення про те, що водень сприяє стабілізації вакансій, що випливає із експериментальних досліджень наводненої та зістареної при $473 \mathrm{~K}$ сталі. Експериментально показано, що зниження температури наводнювання до $358 \mathrm{~K}$ призводить до 
помітного зсуву високотемпературного піку в напрямку вищих температур. Пропонується гіпотеза щодо причини, яка лежить в основі даного явища.

С помощью механической спектроскопии, а именно, измерения внутреннего трения, исследована нержавеющая сталь типа $316 \mathrm{~L}$ в отожжённом и деформированном растяжением состояниях. Низкочастотные измерения внутреннего трения на вынужденных колебаниях проведены в температурном диапазоне от 130 до $500 \mathrm{~K}$ до и после газового наводороживания при $543 \mathrm{~K}$ и трёх значениях давления водорода: 0,5, 10 и 100 МПа. После деформации растяжением в исходном состоянии обнаружены два мультикомпонентных пика при температурах около 250 и 365 К. Показано, что низкотемпературный пик имеет релаксационную природу, в то время как высокотемпературный пик относится к резонансным. Также проверено влияние содержания водорода и его распределения на свойства пиков внутреннего трения, а именно, на их фон, амплитуду и термическую стабильность. Сформулировано предположение о том, что водород способствует стабилизации вакансий, что следует из экспериментальных исследований наводороженной и состаренной при 473 К стали. Экспериментально показано, что снижение температуры наводороживания до $358 \mathrm{~K}$ приводит к заметному сдвигу высокотемпературного пика в направлении больших температур. Предлагается гипотеза, которая объясняет природу данного явления.

Key words: austenitic steel, hydrogen, crystal lattice defects, internal friction.

(Received 27 January, 2014)

\section{INTRODUCTION}

It is well known that many technological processes can provoke hydrogen embrittlement (HE) of engineering materials (see, e.g., Ref. [1]). Intensive development of technologies that use hydrogen as an alternative energy carrier requires ever more materials, which could be used under high-pressure hydrogen gas and in aggressive environments. Over the last fifty years, materials scientists have spent many efforts to find a unique mechanism of HE. As a result of these efforts, three main competing models of HE were proposed: decohesion (e.g., [2]), hydride formation (e.g., [3]) and hydrogen-enhanced local plasticity (HELP) [4].

Having higher enthalpy of hydrogen diffusion, e.g., [5], as compared to nickel or $\alpha$-iron [6], austenitic stainless steels belong to one of the most hydrogen-resistant material types, although they also lose their ductility due to high-pressure gaseous hydrogenation or cathodic hydrogen charging (e.g., [7]). Along with degradation of basic mechanical properties, hydrogen significantly reduces fatigue lifetime of stainless 
steels, and even insignificant content of residual hydrogen in materials (about 2-3 weight $\mathrm{ppm}$ ) can markedly increase fatigue crack growth rate as it was shown by Murakami et al. [8]. The effect of hydrogen was markedly enhanced at low frequencies of loading [8], evidently due to ability of hydrogen clouds accompany dislocations during dislocation slip and due to a difference in densities of $\mathrm{H}$ clouds around the dislocations at high and low frequencies. The influence of hydrogen on the fatigue properties of stainless steels attracts particular attention, with a view to prolonging service lifetime of items working in high-pressure hydrogen environments. Processes which occur in different areas of the plastic zone near the crack tip should be carefully studied in terms of inhomogeneous distribution of stresses, hydrogen concentrations and different substructures in these areas.

It is hard to overestimate the effect, which the interaction of hydrogen atoms with crystal lattice defects produces on the properties of solids. It is responsible for hydrogen diffusion rate in materials, hydrogen distribution and its local concentration, and, consequently, for $\mathrm{H}$ induced local stresses. Measurement of internal friction can give unique microscopic information which cannot be obtained using other experimental techniques. It was successfully used for studies of crystal defects interactions and hydrogen effects in different materials including f.c.c. iron-based alloys subjected to cathodic hydrogen charging (see, e.g., [9]). Taking into account the results obtained by Murakami et $a l$. [8] at low frequencies, there is a need of measuring internal friction of stainless steels under forced sub-resonant vibrations. Usually, internal friction studies of hydrogen charged steels come to measurements of temperature- or amplitude-dependent internal friction (IF) at frequencies that are rarely less than $0.5 \mathrm{~Hz}$ due to specimen shapes.

The aim of the present paper is to study damping properties of type $316 \mathrm{~L}$ steel in the annealed and prestrained states at lowered frequencies and to show how the dissolution of hydrogen in austenitic stainless steel affects interactions between crystal lattice defects. The effect of hydrogen charging temperature will be studied as well.

\section{MATERIALS AND EXPERIMENTAL METHODS}

The material used in the present study was a type of $316 \mathrm{~L}$ austenitic stainless steel (JIS-SUS316L) containing $0.009 \mathrm{C}, 17.22 \mathrm{Cr}, 12.63 \mathrm{Ni}$, 2.26 Mo, 0.32 Si, 1.18 Mn, 0.027 P, 0.001 S (in mass.\%), and Fe in the balance. The wire of $1 \mathrm{~mm}$ diameter was cut into pieces of $170 \mathrm{~mm}$ length, annealed in Ar atmosphere at $1323 \mathrm{~K}$ for 30 minutes and thereafter quenched in water. One set of the wires was left non-deformed, whereas others were tensile prestrained to $2,5,10,15$ and $45 \%$ of elongation, but only two latter as well as the annealed one were chosen for subsequent hydrogen charging as well as annealed one. The pre- 
straining was carried out at room temperature in the laboratory air at the strain rate of $3.3 \cdot 10^{-3} \mathrm{~s}^{-1}$.

The X-ray diffraction tests using $\mathrm{Co} K_{\alpha}$-radiation with wavelength $\lambda=0.178897 \mathrm{~nm}$ revealed only f.c.c. structure of the material studied over all deformation range.

The gaseous hydrogen charging was performed in International Research Centre for Hydrogen Energy at Kyushu University. The temperature of charging was $543 \mathrm{~K}$ and three different hydrogen pressures were applied: $0.5,10$ and $100 \mathrm{MPa}$ for 50,50 and 200 hours, correspondingly. Some specimens were exposed at $358 \mathrm{~K}$ under $100 \mathrm{MPa}$ for 200 hours. After charging, all specimens were stored at $190 \mathrm{~K}$ before being installed in the IF facility. The time needed to install the specimens in the relaxometer did not exceed 20 minutes (including cooling down to $130 \mathrm{~K}$ ).

The hydrogen content was estimated using the method described by Murakami et al. in [10], which had shown satisfactory consistency with experimental data. The calculated values are presented in Table 1.

Values of hydrogen content obtained by means of the thermal desorption analysis (TDA) were very close to calculated ones for the case of hydrogenation at $543 \mathrm{~K}$ and lower 3.5 fold for the case of hydrogenation at $358 \mathrm{~K}$. The calculation of the hydrogen profile for the $316 \mathrm{~L}$ stainless steel square specimen of $1 \mathrm{~mm}$ in thick and the activation enthalpy of hydrogen diffusion $H_{\text {diff }}=67.7 \mathrm{~kJ} / \mathrm{mol}$ and $D_{0}=4.66 \cdot 10^{-5}$ $\mathrm{m}^{2} / \mathrm{s}$ was performed using the following equations:

$$
\begin{gathered}
C_{\mathrm{H}}(x)=C_{0}\left(\operatorname{erfc}\left(\frac{x}{2 \sqrt{D t}}\right)+\operatorname{erfc}\left(\frac{l-x}{2 \sqrt{D t}}\right)\right), \\
\quad \text { if }\left(\operatorname{erfc}\left(\frac{x}{2 \sqrt{D t}}\right)+\operatorname{erfc}\left(\frac{l-x}{2 \sqrt{D t}}\right)\right)<1,
\end{gathered}
$$

and

$$
C_{\mathrm{H}}(x)=C_{0} \text {, if }\left(\operatorname{erfc}\left(\frac{x}{2 \sqrt{D t}}\right)+\operatorname{erfc}\left(\frac{l-x}{2 \sqrt{D t}}\right)\right) \geq 1 \text {, }
$$

TABLE 1. Estimated hydrogen content in studied steel after hydrogen charging.

\begin{tabular}{c|c|c|c|c}
\hline $\begin{array}{c}\text { Hydrogen gas pressure, } \mathrm{MPa} \\
\text { (temperature of charging) }\end{array}$ & $\begin{array}{c}0.5 \\
(543 \mathrm{~K})\end{array}$ & $\begin{array}{c}10 \\
(543 \mathrm{~K})\end{array}$ & $\begin{array}{c}100 \\
(543 \mathrm{~K})\end{array}$ & $\begin{array}{c}100 \\
(358 \mathrm{~K})\end{array}$ \\
\hline Fugacity, MPa & 0.5 & 10.4 & 142 & 170.3 \\
Hydrogen content, weight ppm & 6.1 & 28.0 & 103.5 & 83.5 \\
(TDA data) & $(5.8)$ & $(25.6)$ & $(99.1)$ & $(23.9)$ \\
\hline
\end{tabular}


where $x$ is the coordinate, $l$-the specimen thickness, $t$-time of charging, $D$-diffusion coefficient and $C_{0}$ is equilibrium concentration on the surface which is proportional to the hydrogen fugacity. Figure 1 shows the cross-section distribution of the normalized (i.e. $\left.C_{0}=1\right)$ hydrogen concentration in the case of hydrogenation at $358 \mathrm{~K}$ for 200 hours (Fig. 1, $a$ ) and $543 \mathrm{~K}$ for 50 and 200 hours (Fig. 1, b).

As one can see, the distribution of hydrogen after hydrogenation at $543 \mathrm{~K}$ is uniform for charging time longer than 3 hours, whereas the penetration depth is much smaller in the case of exposure at $358 \mathrm{~K}$ (Fig. 1,a). So, the hydrogen profile is formed in the latter case but hydrogen concentration is higher in the surface layer due to higher hydrogen fugacity.

Internal friction measurements were carried out using an installation made by Nihon TechnoPlus [11]. With this equipment, IF can be measured by the sub-resonant forced vibrations method employing an inverted torsion pendulum within the frequency range from 0.001 to $0.5 \mathrm{~Hz}$ and temperature range from 120 to $720 \mathrm{~K}$, with the strain amplitudes from $10^{-6}$ to $2 \cdot 10^{-4}$ and the heating rate of $0.033 \mathrm{~K} / \mathrm{s}$. The frequency of characteristic vibrations of the system was about $50 \mathrm{~Hz}$ for standard specimen of $20 \mathrm{~mm}$ long and $1 \mathrm{~mm}$ in diameter. All temperature dependences were obtained at the strain $5 \cdot 10^{-5}$, i.e. in the amplitude-independent area. Simultaneously with the internal friction, the values of the reciprocal in-phase component of dynamic modulus can be measured. Some specimens were exposed at $473 \mathrm{~K}$ for 12 hours in vacuum without taking them out of pendulum holders with the aim to test the thermal stability of IF peaks after hydrogen left the specimen.
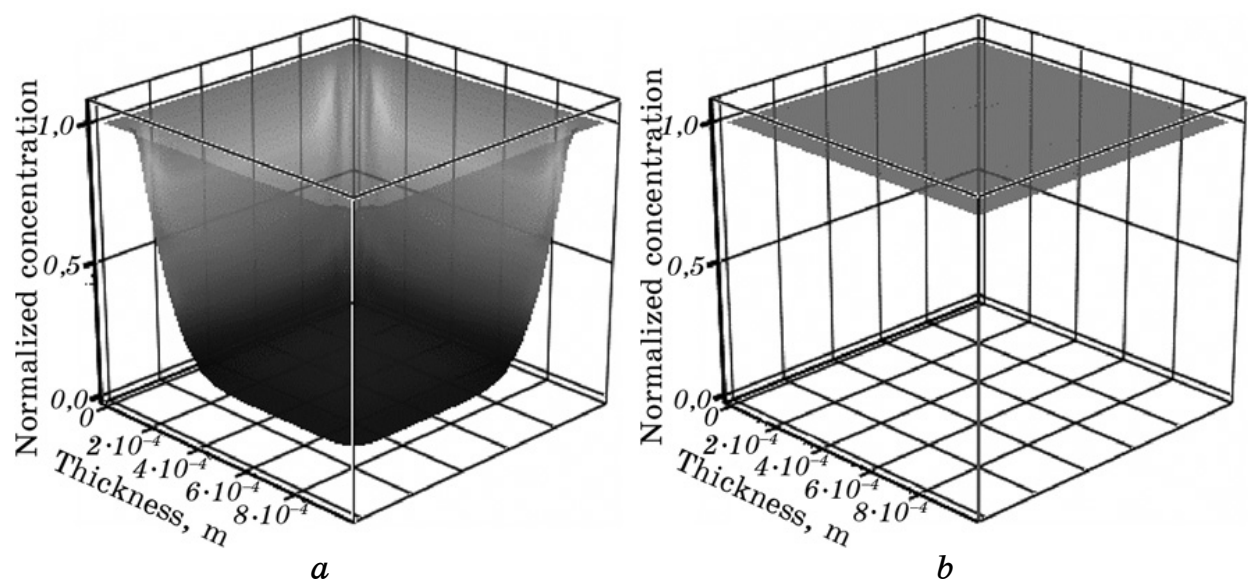

Fig. 1. Normalized hydrogen concentration profile in type 316L steel charged under $100 \mathrm{MPa}$ and $358 \mathrm{~K}$ for 200 hours $(a)$ and $543 \mathrm{~K}$ for 50 and 200 hours (b). 


\section{RESULTS AND DISCUSSION}

\subsection{Hydrogen Effect on Interaction between the Lattice Defects}

Internal friction measurements of every set of specimens were conducted at three frequencies of $0.3,0.1$ and $0.05 \mathrm{~Hz}$. The upper frequency limit was chosen because the minimal natural frequency was about $35 \mathrm{~Hz}$ and the choice of the lowest one was due to the necessity of obtaining an optimal number of experimental points in the chosen temperature range. The spectra obtained were grouped into three categories: those with the identical measurement frequency, prestrain degree, and charging conditions.

Figure 2, $a$ shows the temperature-dependent IF spectra in the annealed hydrogen-free specimen. One can distinguish a trace of the peak at about $250 \mathrm{~K}(\mathrm{P} 1)$ at $0.3 \mathrm{~Hz}$. A well-defined complex peak arises at about $365 \mathrm{~K}(\mathrm{P} 2)$ at $0.05 \mathrm{~Hz}$. Its amplitude decreases rapidly with increasing frequency of measurement.

Figure 2, $b$ shows the effect of deformation on the IF spectra in hydrogen-free specimens. The tensile deformation to $15 \%$ of elongation of the annealed specimen results in an increase of the IF background, very likely due to multiplication of dislocations, and a significant increase in P1 and P2 amplitudes. The deformation to $45 \%$ led to a decrease in the absolute peak amplitudes, as compared with that of $15 \%$, to broadening of both peaks and their shift towards low temperatures for $\mathrm{P} 1$ and towards high temperatures for P2. The peaks are much broader than Debye peak, which suggests a variety of relaxation time values. The deformation dependences of $\mathrm{P} 1$ and $\mathrm{P} 2$ temperatures for uncharged steel are presented in Fig. 3.
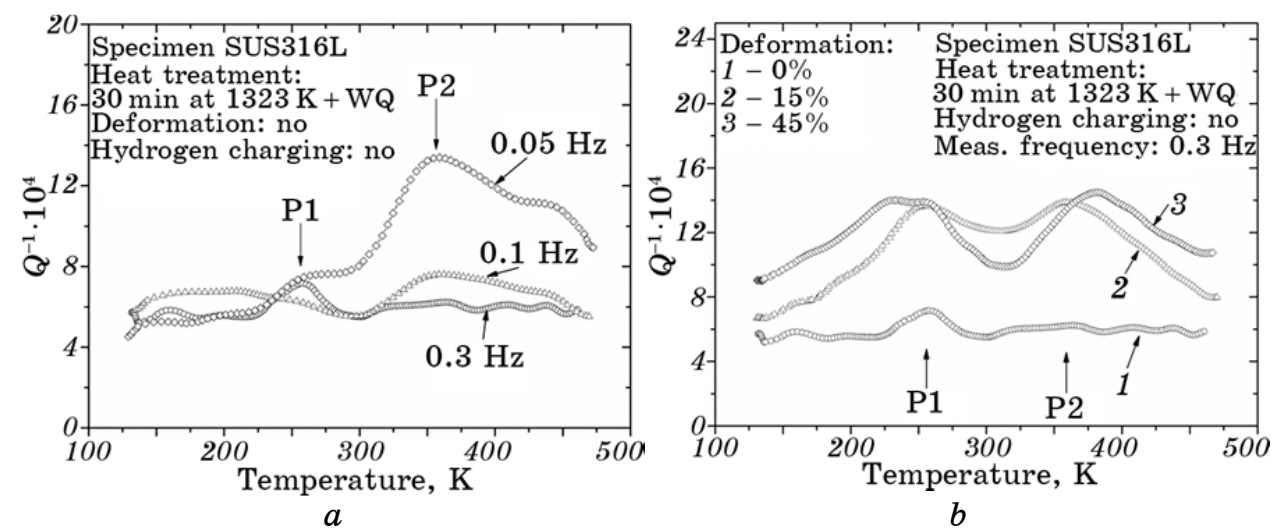

Fig. 2. Internal friction spectra of annealed type 316L steel measured at 0.3 , 0.1 and $0.05 \mathrm{~Hz}(a)$, and before and after tensile deformation measured at $0.3 \mathrm{~Hz}(b)$. 


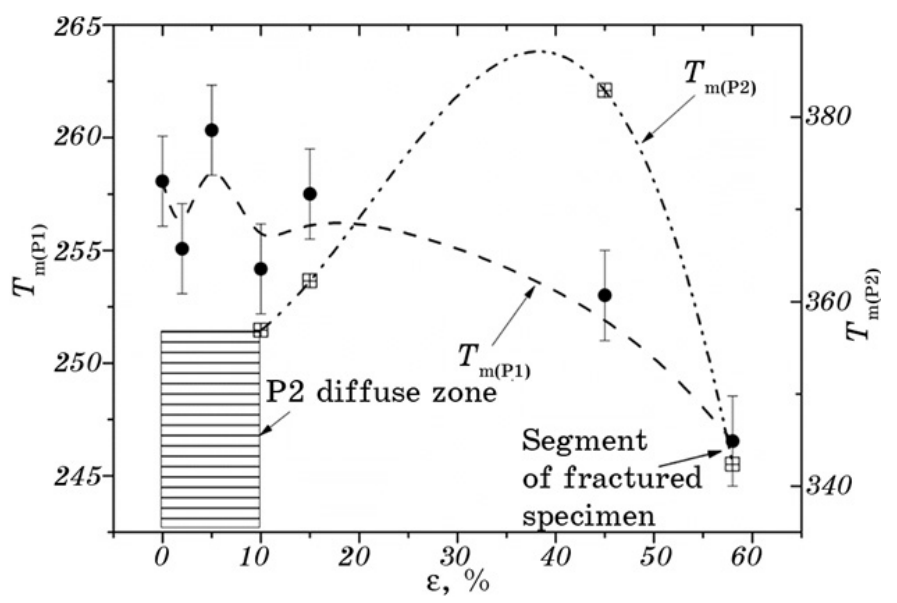

Fig. 3. Dependences of P1 and P2 maxima temperatures on prestrain degree for uncharged type $316 \mathrm{~L}$ steel.

The P1 peak temperature gradually decreases with a narrow local maximum at about $5 \%$ of deformation, whereas the shape of P2 remains vague up to $10 \%$ of deformation. Its temperature rises and then abruptly drops at the ultimate deformation.

Figure 4 shows temperature-dependent IF spectra with different hydrogen charging pressures. Hydrogen gaseous charging of the annealed specimens leads to an increase in P1 amplitude, depending on the hydrogen content, and its abrupt shift towards lower temperatures (Fig. 4,a). The peak P2 rises with an increase in hydrogen content and with decreasing measurement frequency (Fig. 4, $a, b$ ).

In all deformed specimens, the IF background and P1 peak decrease after low-pressure (0.5 MPa) hydrogen charging (Fig. 4, c, d). At the same time, with increasing hydrogen pressure, P1 peak grows and slightly moves towards lower temperatures, whereas the IF background remains unchanged. Hydrogen charging at $543 \mathrm{~K}$ independently of its pressure almost entirely suppresses $\mathrm{P} 2$ at $0.3 \mathrm{~Hz}$ in the deformed material (Fig. 4,a), whereas it grows with decreasing measurement frequency and increased hydrogen content (Fig. 4, d).

Figure 5 shows a comparison of IF spectra of hydrogen-charged samples before and after the annealing at $473 \mathrm{~K}$ in vacuum for 12 hours. Both peaks are completely suppressed in all uncharged samples (Fig. 5, a). In contrast, the low-temperature $\mathrm{P} 1$ peak remains more stable in hydrogen-charged prestrained specimens (Fig. 5, b, c). Such a treatment also reduces IF background of the deformed uncharged specimens but it remains stable in the deformed hydrogen-charged steel (Fig. 5, $a, c$ ). The annealing is accompanied by the recovery of the shear modulus and this recovery is more pronounced in the uncharged spec- 

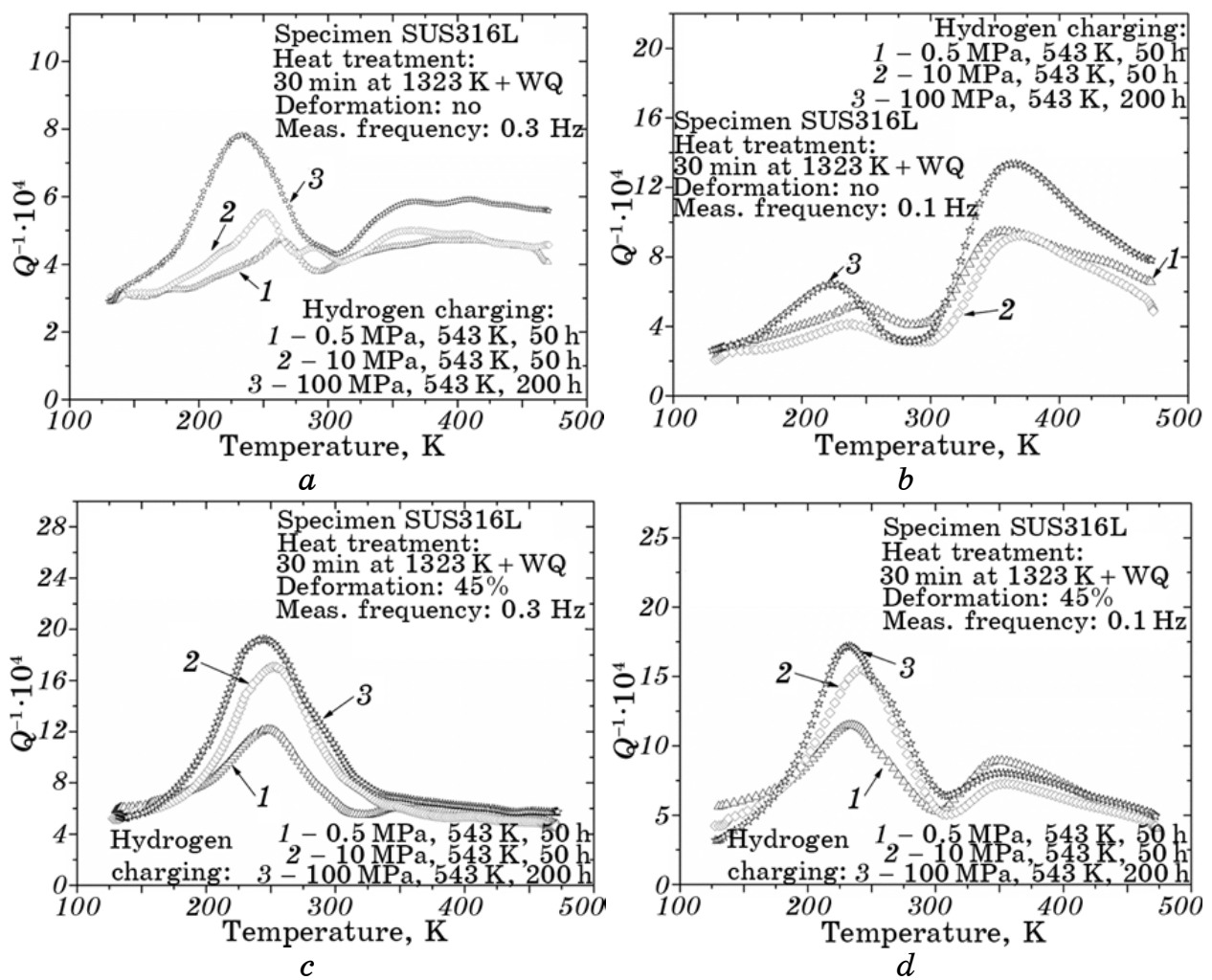

Fig. 4. Internal friction spectra of type $316 \mathrm{~L}$ steel after hydrogenation under three different pressures: annealed steel, measurement frequency $0.3 \mathrm{~Hz}(a)$; annealed steel, measurement frequency $0.1 \mathrm{~Hz}(b) ; 45 \%$-deformed steel, measurement frequency $0.3 \mathrm{~Hz}(c) ; 45 \%$-deformed steel, measurement frequency $0.1 \mathrm{~Hz}(d)$.

imens than in the hydrogenated ones. In contrast to deformed hydrogen-charged steel, the hydrogen-caused peaks completely disappeared after annealing of non-deformed steel even in the specimens having the highest hydrogen content (Fig. 5, $d$ ).

Before discussing the results obtained in the present study, one should determine and interpret the effect of the following factors on steel microstructure: a) prestrain, b) temperatures of hydrogen charging and annealing, and c) hydrogen dissolution and hydrogen content.

It is well known that the density of crystal lattice defects increases essentially during plastic deformation of metals due to activation of dislocation sources and interaction of moving dislocations with the dislocation forest, resulting in generation of dislocation jogs, which are the sources of point defects (vacancies and self-interstitial atoms). In this case, the point defects are thermodynamically non-equilibrium 


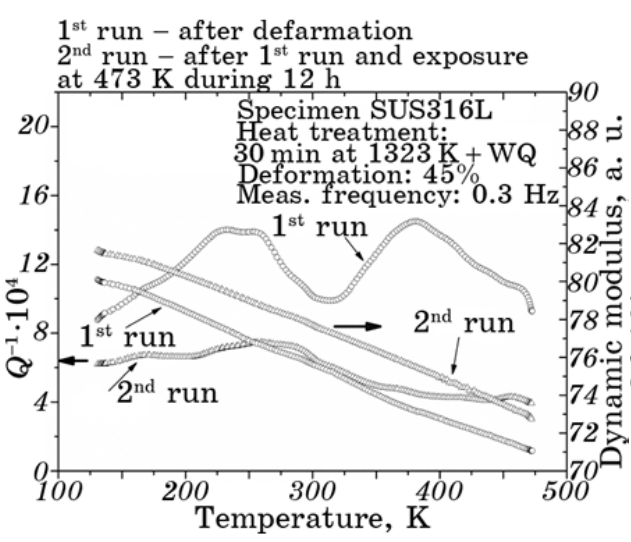

$a$

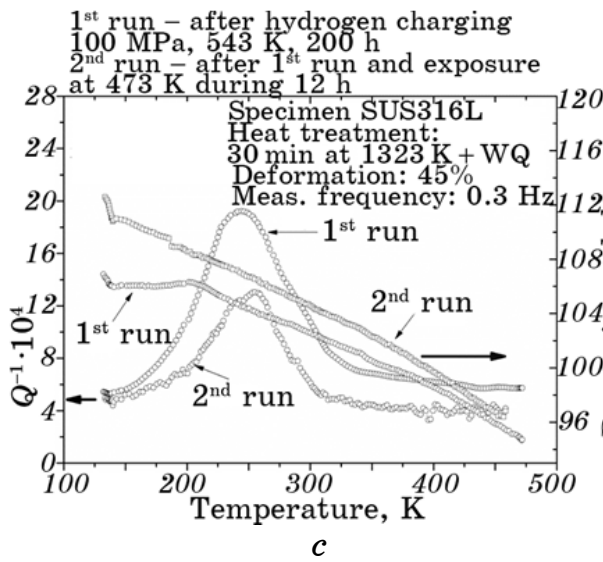

1 st $\mathrm{run}-$ after hydrogen charging $2^{\text {nd }}$ run, after $1^{\text {tst }}$ run and exposure

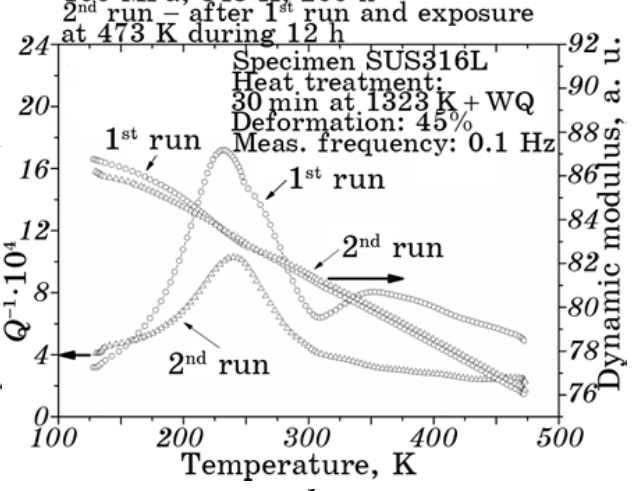

$b$ $1_{1}^{\text {st }}$ run - after hydrogen charging

$2^{\text {nd }}$ run $\bar{K}$ after $1^{\text {st }}$ run and exposure

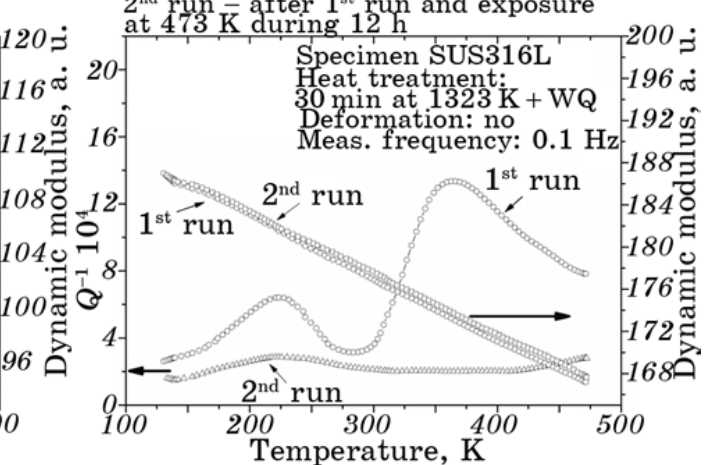

$d$

Fig. 5. Temperature dependences of internal friction and dynamic modulus of type $316 \mathrm{~L}$ steel: after $45 \%$ deformation ( $1^{\text {st }}$ run) and after annealing in vacuum at $473 \mathrm{~K}$ for $12 \mathrm{~h}\left(2^{\text {nd }}\right.$ run), measurement frequency $0.3 \mathrm{~Hz}(a)$; the same as (a) obtained at $0.1 \mathrm{~Hz}(b)$; after $45 \%$ deformation and gaseous hydrogen charging under $100 \mathrm{MPa}\left(1^{\text {st }}\right.$ run $)$ and after annealing in vacuum at $473 \mathrm{~K}$ for $12 \mathrm{~h}\left(2^{\text {nd }}\right.$ run $)(c)$; for annealed steel and $100 \mathrm{MPa}$ hydrogen charged steel $\left(1^{\text {st }}\right.$ run) and after annealing in vacuum at $473 \mathrm{~K}$ for $12 \mathrm{~h}\left(2^{\text {nd }}\right.$ run $)(d)$.

ones. But vacancies tend to clustering, in contrast to self-interstitial atoms whose concentration is very low due to their large formation enthalpy. They can also quickly sink to dislocations and grain boundaries owing to their high mobility [12].

The dissolution of hydrogen in steels increases the thermodynamic equilibrium concentration of vacancies as it was predicted theoretically by Smirnov et al. [13], and later confirmed by Fukai et al. [14] for $\mathrm{Ni}-\mathrm{H}$ and $\mathrm{Pd}-\mathrm{H}$ alloys and Gavriljuk et al. [15] for austenitic steel. According to [16], the increase in their concentration could lead to the increased stability of hydrides in the hydride-forming elements, to the 
enhancement of metal atom diffusion and, in some cases, to the enhancement of creep. The suggestion about the primary role of hydrogen-induced vacancies in hydrogen-related failure was made by Nagumo et al. [17] in the framework of the hydrogen-enhanced straininduced vacancy model [18].

As concerns the effect of temperature, the hydrogen charging was carried out at temperatures when the first or even second stage (polygonization) of recovery can occur. The first stage of recovery is characterized with a decrease in the point defects density, their annihilation and their sinking to the dislocations and grain boundaries, and the redistribution of dislocations without the formation of new boundaries. Although the polygonization of deformed materials occurs within the temperature range of $(0.3-0.4) T_{\text {melt }}$, with $T_{\text {melt }}=1713 \mathrm{~K}$ for the steel studied, the dissolved hydrogen atoms can facilitate this process through the enhancement of metal atom diffusion and the increase in dislocation mobility. The comparison of the IF results obtained after hydrogen charging at lower temperature can clarify the situation. Such a study was done and will be described in subsection 3.2 of the present paper. The ageing at $473 \mathrm{~K}$ in vacuum for 12 hours of annealed and hydrogen-charged specimens was performed, to test the influence of the effect of the temperature per se in comparison with that of hydrogen charging.

Therefore, there are three competing factors which counteract each other: plastic deformation and hydrogen entry increase the density of crystal lattice defects, whereas the hydrogen charging temperature has the opposite effect.

The IF peaks caused by plastic deformation in the austenitic stainless steel was studied earlier by Ivanchenko et al. [19]. They suggested that the P1 peak was associated with the stress-assisted unpinning of dislocations from point defects (Hasiguti-like peak), and P2 peak is related to the annihilation of point defects at dislocation cores. Indeed, taking into account a linear rise of the low-temperature internal friction background measured at $150 \mathrm{~K}$ and shown in Fig. 6, $a$, the dependence of the peak height on the deformation degree is typical for Hasiguti relaxation resulting from dislocation-vacancy interaction [20]. Fouquet et al. [21] obtained similar results on polycrystalline copper deformed at room temperature. In the annealed material, concentration of point defects and the dislocation density are low and their distribution is rather random, so that their effect on the temperature dependence of IF is minimal (Fig. 2, $a$ ). Plastic deformation increases essentially both parameters, and their effect on internal friction becomes more pronounced and then gradually decreases (Fig. 6,a).

Such behaviour can be related to the change in the $c_{\text {vac }} / d_{\text {disl }}$ ratio during plastic deformation, where $c_{\text {vac }}$ and $d_{\text {disl }}$ are concentration of vacancies and density of dislocations, respectively. After hydrogen charging 

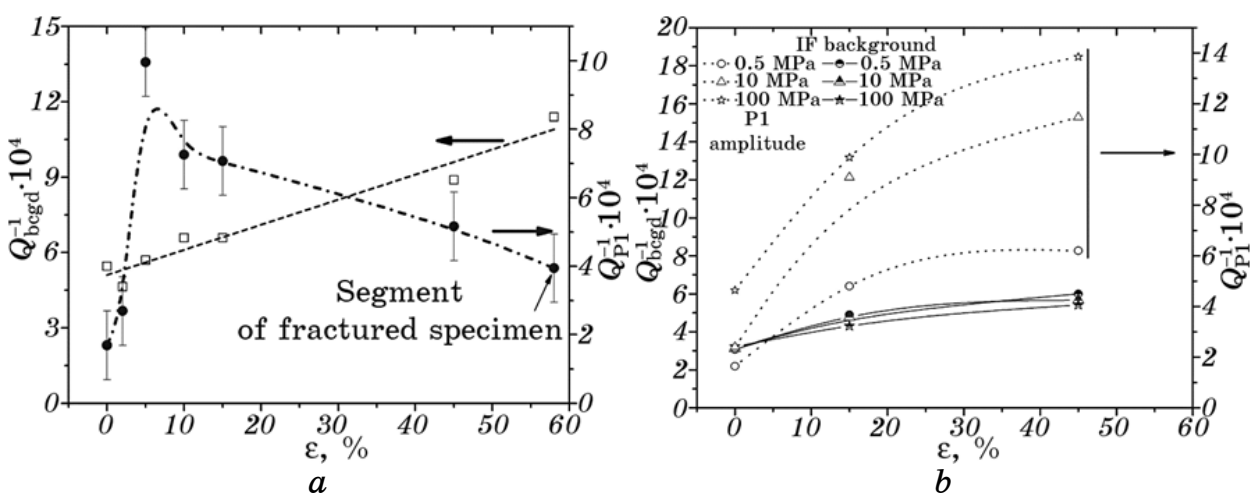

Fig. 6. Dependences of low-temperature IF background and P1 amplitude on prestrain degree (at $f=0.3 \mathrm{~Hz}$ ): for hydrogen-free steel $(a)$, for steel charged with hydrogen under different pressures $(b)$.

under different pressures, the growth of internal friction background with the degree of prestrain is much smaller than in the hydrogen-free material and is not dependent on the hydrogen content. The P1 peak after hydrogen charging demonstrates a different behaviour (Fig. 6, b). In contrast to hydrogen-free material, its amplitude rises with increasing in hydrogen content in all cases. Given that hydrogen dissolution does not affect the concentration of dislocations in the absence of external stresses but can increase essentially the thermodynamic equilibrium concentration of vacancies that do not form clusters, so ratio $c_{\text {vac }} / d_{\text {disl }}$ increases.

The position of the P1 peak always shifts towards lower temperatures with decreased frequency of measurement, which confirms its relaxation nature (Fig. $4, c, d$ ). The behaviour of $\mathrm{P} 2$ peak is more complex. Its position can shift in both directions with frequency decrease. One can state with confidence that P2 peak height strongly depends on the measurement frequency and always grows with frequency decrease (Fig. 4, $a, b$ ). This fact can indicate its resonance nature [22]. The suggestion expressed in [19] that P2 peak is linked with the annihilation of point defects (vacancies), i.e. with dislocation climbing, seems to be very likely. The P2 peak position and intensity may be affected by the length of vacancy diffusion path before annihilation, i.e., dislocation density and the number of vacancies in vacancy complexes. The thermally activated dilution of Cottrell atmospheres or dissociation of the 'hydrogen atom-vacancy (vacancies)' complexes could be other factors, which influence P2 peak behaviour.

As concerns the position of the relaxation $\mathrm{P} 1$ peak, it is affected by two main parameters - the activation enthalpy $\Delta H$ and preexponential factor $\tau_{0}$ of the relaxation time. The relaxation time expressed as $\tau=\tau_{0} \exp \{\Delta H /(k T)\}$ represents the reciprocal frequency of the jumps of 
defects to overcome an energy barrier $\Delta H$ at temperature $T$. Thus, preexponential factor $\tau_{0}$ is relaxation time at $T \rightarrow \infty$. The activation enthalpy is only determined by the peak behaviour at changes in the measurement frequency. For this reason, the shift of the peak towards lower temperatures with an increase in deformation degree does not always mean weakening of the interaction between the pinning points and dislocations. For any relaxation processes, with a drop in frequency, the peak always moves towards lower temperatures, and activation enthalpy can be determined in the Arrhenius co-ordinates (i.e. $\ln \omega$ vs. $1 / T)$, using the following equation:

$$
\ln \frac{\omega_{2}}{\omega_{1}}=\frac{\Delta H}{k}\left(\frac{1}{T_{\mathrm{m} 1}}-\frac{1}{T_{\mathrm{m} 2}}\right)
$$

$k$ is Boltzmann constant; $T_{\mathrm{m} 1}$ and $T_{\mathrm{m} 2}$ are the temperatures of the peaks at measurement frequencies $\omega_{1}$ and $\omega_{2}$, correspondingly.

It should be noted that the relaxation peak associated with jumps of hydrogen atoms dissolved in the crystal lattice of annealed austenitic stainless steels, the so-called Snoek-like peak, is usually observed in the temperature range $215-220 \mathrm{~K}$ at about $1 \mathrm{~Hz}$ of measurement frequency [23]. Its activation enthalpy is equal to 46.15-52.9 $\mathrm{kJ} \cdot(\mathrm{mol} \cdot \mathrm{K})^{-1}$, depending on chemical composition. In the present study, such a peak was expected at temperatures 8-15 K lower, i.e. at 200$210 \mathrm{~K}$, depending on measurement frequency. However, we can only

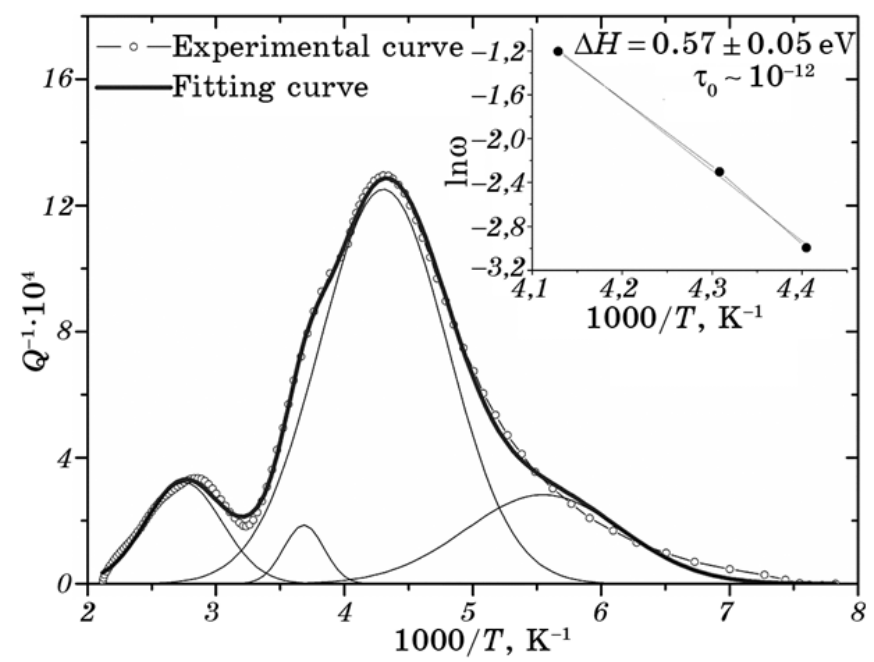

Fig. 7. An example of internal friction peak fitting of $45 \%$-deformed type $316 \mathrm{~L}$ steel after gaseous hydrogen charging under $100 \mathrm{MPa}$ at $543 \mathrm{~K}$. The treatment of the experimental data in the Arrhenius co-ordinates is shown as inset. 
speak about traces of such a peak as a part of the low-temperature P1 peak resulting from dislocation-point defect interaction in the deformed and charged steels. It could mean that almost all hydrogen atoms are trapped by crystal lattice defects, such as dislocations and vacancies. A stronger dependence of the P1 peak position on hydrogen content in annealed steel (Fig. 4, $a$ ) as compared to that in the deformed material, could be the result of saturation of trapping sites with hydrogen atoms.

The activation enthalpies of the P1 peak were obtained from the experimental spectra. Figure 7 presents an example of peak fitting for the hydrogen-charged steel and the treatment of data in the Arrhenius co-ordinates.

The fitting of experimental spectra was performed twice, using Gaussian peaks and broadened Debye peaks with the width parameter $\beta=2.66-2.94$. Both methods gave identical results. Three components were used for fitting P1 peak and from 1 to 3 for P2 peak, depending on the state of steel. Due to complex nature of the P1 peak, the estimation could be performed only for the strongest component and was quite coarse. Table 2 contains the data obtained.

The activation enthalpy $\Delta H$ for the $\mathrm{P} 1$ peak in the annealed steel does not practically change with increasing hydrogen content and is close to values obtained earlier for Snoek-like relaxation [23]. One can see that deformation per se increases essentially the activation enthalpy and reduces the preexponential factor $\tau_{0}$ (Table 2), most likely due to formation of strong pinning points at the intersections of dislocations, i.e. shortening of dislocation segments. Hydrogen charging at $543 \mathrm{~K}$ led to reduction of $\Delta H$, probably due to recovery processes, but $\Delta H$ slightly increased with rising hydrogen content, i.e. vacancy concentration. The $\tau_{0}$ parameter dropped with an increase in hydrogen concentration for all specimens. It should be mentioned that the values of $\tau_{0}$ are large compared to the ones for solute diffusion and, in fact, more dislocation-like, as required for Hasiguti-types of dislocation-point defect processes.

TABLE 2. Activation enthalpy of the low-temperature P1 peak.

\begin{tabular}{c|ccc}
\hline \multirow{2}{*}{ Hydrogen pressure } & \multicolumn{3}{|c}{$\Delta H( \pm 0.5), \mathrm{kJ} \cdot(\mathrm{mol} \cdot \mathrm{K})^{-1}\left(\right.$ order of $\left.\tau_{0}, \mathrm{~s}\right)$} \\
\cline { 2 - 4 } & 0 & 15 & 45 \\
\cline { 2 - 4 } & - & $51.0\left(10^{-10}\right)$ & $67.3\left(10^{-12}\right)$ \\
\hline Uncharged & $49.0\left(10^{-9}\right)$ & $51.9\left(10^{-10}\right)$ & $49.0\left(10^{-10}\right)$ \\
$0.5 \mathrm{MPa}$ & $46.2\left(10^{-9}\right)$ & $45.2\left(10^{-10}\right)$ & $56.7\left(10^{-10}\right)$ \\
$10 \mathrm{MPa}$ & $51.0\left(10^{-11}\right)$ & $53.8\left(10^{-12}\right)$ & $54.8\left(10^{-12}\right)$ \\
$100 \mathrm{MPa}$ & &
\end{tabular}




\subsection{The effect of Hydrogen Charging Conditions on IF Spectra of Deformed Steel}

Figure 8 presents temperature dependences of IF for the $45 \%$ deformed type 316L steel and those obtained after hydrogen charging under $100 \mathrm{MPa}$ at two different temperatures (358 and $543 \mathrm{~K}$ ). Saturation with hydrogen at $543 \mathrm{~K}$ led to reduction of IF background that could be attributed to pinning of dislocations by hydrogen atoms or else to recovery processes occurring at this temperature, because IF background is only controlled by vibration-induced motion of dislocations in this temperature range of measurements.

The hydrogen charging performed at $358 \mathrm{~K}$ did not change the IF background, but the absolute amplitude of the P1 peak became higher. We suggest that the reason for the drop in the background is the very recovery processes that occurred during hydrogen charging at $543 \mathrm{~K}$ leading to a reduction in dislocation density. Moreover, the penetration depth of hydrogen during hydrogen charging carried out at lower temperature is much smaller (see Fig. 1), but hydrogen fugacity, and thus its equilibrium concentration, is higher than in the case of high temperature charging (see Table 1 ). So, the concentration of hydrogen in the surface layer (Fig. 1), strongly affecting IF, was much higher after charging at $358 \mathrm{~K}$. At the same time, the high-temperature component of IF spectra, P2 peak, shifted towards higher temperatures by about $60 \mathrm{~K}$. A search in available scientific literature related to internal friction studies of hydrogen-doped materials suggests that this un-

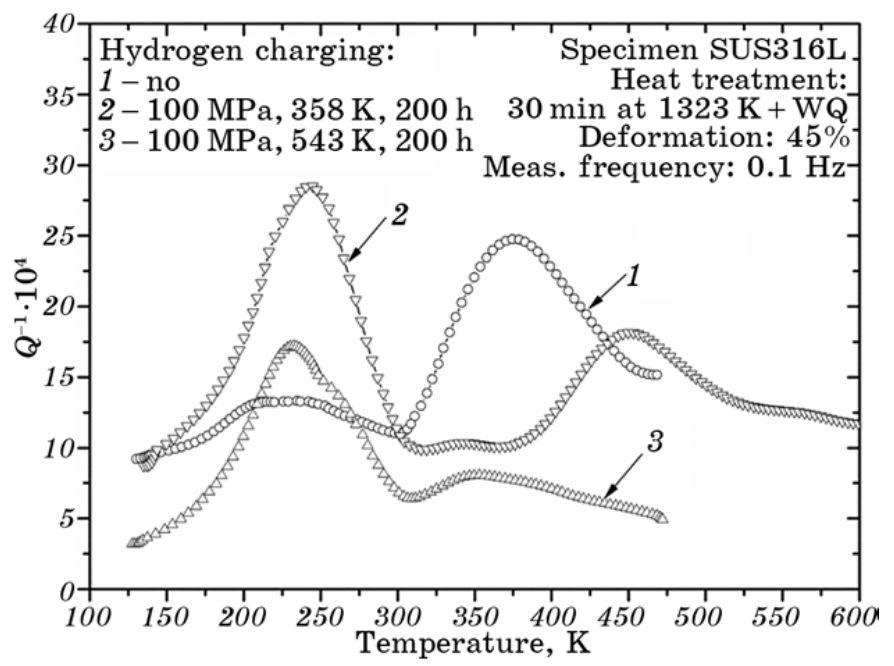

Fig. 8. Internal friction spectra of $45 \%$-deformed type $316 \mathrm{~L}$ steel before (curve 1) and after gaseous hydrogen charging under $100 \mathrm{MPa}$ at $358 \mathrm{~K}$ (curve 2) and $543 \mathrm{~K}$ (curve 3). 
expected result has been obtained for the first time.

Let us discuss a possible reason underlying this phenomenon. It was mentioned above that the P2 peak in the deformed stainless steel is related to annihilation of point defects (vacancies). Two reasons could account for the shift of this component towards higher temperatures: formation of vacancy clusters or 'vacancy $-N$ hydrogen atoms' complexes. Ab initio calculations made for $\mathrm{Al}$ [24] and $\alpha-\mathrm{Fe}$ [25] have shown that a single vacancy can trap up to 12 hydrogen atoms in $\mathrm{Al}$ and up to 6 atoms in $\alpha-\mathrm{Fe}$. Binding energy of hydrogen atoms with vacancies decreases with an increase in the number of hydrogen atoms in the complex. On the other hand, positron annihilation studies of cathodically charged (i.e. saturated under high hydrogen fugacity and at low temperature) iron [26], stainless steels [27] and nickel [28], have given evidence that hydrogen contributes to the formation of vacancy clusters and increases the recovery temperature. These results are more suitable for the interpretation of IF spectra as the dissociation of 'hydrogen atoms-vacancy clusters' complexes is expected at higher temperatures than the dissociations of 'single vacancy-hydrogen atom (atoms)' complexes.

\section{SUMMARY}

Two complex internal friction peaks (P1 and P2) were observed in the annealed and prestrained type 316L austenitic steel before and after gaseous hydrogen charging. In our opinion, the amplitude of the peak $\mathrm{P} 1$ is associated with a change in the $c_{\mathrm{vac}} / d_{\text {disl }}$ ratio during preliminary plastic deformation and hydrogen saturation. Hydrogen dissolution increases the amplitude of the P1 peak and stabilizes it due to the hydrogen-caused rise in the concentration of thermodynamic equilibrium vacancies. The estimation of the P1 peak activation enthalpy revealed a tendency to increasing after plastic deformation and to decreasing after hydrogen charging. The activation enthalpy slightly grows with hydrogen concentration. The preexponential factor decreases with increasing preliminary deformation and hydrogen concentration.

The behaviour of the peak P2 is rather complicated and does not demonstrate noticeable patterns. One can observe an abrupt rise of its amplitude with decreasing measurement frequency, which indicates its resonant nature. The hydrogen charging suppresses P2 peak in the prestrained steel in contrast to the annealed material. The temperature of gaseous hydrogen charging has a remarkable effect on the behaviour of this peak in the deformed steel, which could be accounted for the formation of 'hydrogen atoms-vacancy clusters' complexes during hydrogen charging at temperatures below their dissociation.

The author thanks Prof. V. G. Gavriljuk (G. V. Kurdyumov Institute for Metal Physics, National Academy of Sciences of Ukraine) for 
his comments and fruitful discussion.

\section{REFERENCES}

1. D. H. Herring, Wire Forming Technol. Int., 13: 24 (2010).

2. E. A. Steigerwald, F. W. Schaller, and A. R. Troiano, Trans. Metall. Soc. AIME, 218: 832 (1960).

3. A. Szumer and A. Janko, Corrosion, 35: 461 (1979).

4. H. K. Birnbaum and P. Sofronis, Mater. Sci.Eng. A, 176: 191 (1994).

5. $\quad$ N. R. Quick and H. H. Johnson, Metall. Trans. A, 10: 67 (1979).

6. A. M. Brass, A. Chanfreau, and J. Chene, Hydrogen Effects on Material Behaviour (Eds. A. W. Thompson and N. R. Moody) (Warrendale: TMS Publishing: 1990), p. 19.

7. J. P. Hirth, Metall. Trans. A, 11: 861 (1980).

8. Y. Murakami, T. Kanezaki, Y. Mine, and S. Matsuoka, Metall. Mater. Trans.A, 39: 1327 (2008).

9. V. N. Shivanyuk, J. Foct, and V. G. Gavriljuk, Mater. Sci. Eng. A, 300: 284 (2001).

10. Y. Murakami, T. Kanezaki, and Y. Mine, Metall. Mater. Trans. A, 41: 2548 (2010).

11. http://www.nihon-tp.com/index.htm

12. W. Pfeiler, Alloy Physics (Weinheim: Wiley-WCH: 2007).

13. A. M. Bobyr', V. N. Bugaev, and A. A. Smirnov, Reports of Academy of Sciences of USSR, 320: 1113 (1991).

14. Y. Fukai and N. Okuma, Japan J. Appl. Phys., 32: L1256 (1993).

15. V. G. Gavriljuk, V. N. Bugaev, Yu. N. Petrov, A. V. Tarasenko, and Z. Yanchitski, Scripta Mater., 34: 903 (1996).

16. Y. J. Fukai, Alloys Compd., 356-357: 263 (2003).

17. K. Takai, H. Shoda, H. Suzuki, and M. Nagumo, Acta Mater., 56: 5158 (2008).

18. M. Nagumo, Mater. Sci. Technol., 20: 940 (2004).

20. M. Ivanchenko, Y. Yagodzinskyy, and H. Hanninen, Mater. Sci.Eng. A, 521522: 121 (2009).

21. M. S. Blanter and Yu. V. Piguzov, Internal Friction Method in Metal Science Studies (Moscow: Metallurgiya: 1991).

22. J. de Fouquet, P. Boch, J. Petit, and G. J. Rieu, Phys. Chem. Solids, 31: 1901 (1970).

23. M. A. Krishtal and S. A. Golovin, Internal Friction and Materials Structure (Moscow: Metallurgiya: 1976).

24. V. G. Gavriljuk, V. N. Shyvaniuk, and J. Foct, Acta Mater., 51: 1293 (2003).

25. G. Lu and E. Kaxiras, Phys. Rev. Let., 94: 155501 (2005).

26. Y. Tateyama and T. Ohno, Phys. Rev. B, 67: 174105 (2003).

27. K. Sakaki, T. Kawase, M. Hirato, M. Mizuno, H. Araki, Y. Shirai, and M. Nagumo, Scr. Mater., 55: 1031 (2006).

28. Y. Q. Chen, Y. C. Wu, Z. Wang, and S. J. Wang, Radiat. Phys. Chem., 76: 308 (2007).

29. Y. C. Wu, Y. Itoh, and Y. Ito, physica status solidi (b), 193: 307 (1996). 